The Israeli J ournal of Aquaculture - Bamidgeh, IJ A_69.2017.1380, 7 pages

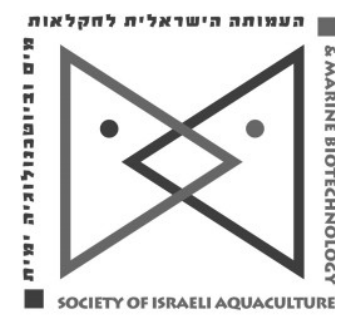

The IJ A appears exclusively as a peer-reviewed on-line open-access journal at http://www. siamb. org.il. To read papers free of charge, please register online at registration form.

Sale of IJ A papers is strictly forbidden.

\title{
Effects of Antimicrobial Peptides Surfactin Administration on Growth Performance, I ntestinal Digestive Enzymes Activities and Some Serum Biochemical Parameters of Orange-spotted Grouper (Epinephelus coioides) J uveniles
}

\author{
Shao-Wei Zhai ${ }^{1,2 *}$, Xiu-Wen Sun ${ }^{1}$, Xue-Hao Chen ${ }^{1,2}$ \\ ${ }^{1}$ Fisheries College of J imei University, China \\ ${ }^{2}$ Engineering Research Center of the Modern Industry Technology for Eel, \\ Ministry of Education, China
}

Keywords: Surfactin; orange-spotted grouper; growth, digestive enzymes; serum biochemical parameters

\begin{abstract}
This trial was conducted to investigate the effects of dietary surfactin supplementation on the growth performance, intestinal digestive enzyme activities, and some serum biochemical parameters of orange-spotted grouper (Epinephelus coioides) juveniles. Three hundred and sixty fish were randomly divided into six treatment groups with four replicates in each group and 15 fish in each replicate. The dietary surfactin levels of four treatment groups were 0 (control group), 25, 50, 100, 150, and $200 \mathrm{mg} / \mathrm{kg}$, respectively. The trial period was 8 weeks. Compared with the control group, final body weight, weight gain rate, and feed conversion ratio were improved significantly by $100 \mathrm{mg} / \mathrm{kg}$ surfactin supplementation $(P<0.05)$. No significant differences of feeding rate and survival rate were found between the control group and all surfactin supplementation groups $(P>0.05)$. Protease and lipase activity in intestine of 50,100 , and $150 \mathrm{mg} / \mathrm{kg}$ surfactin supplementation groups were significantly higher than those of the control group $(P<0.05)$. Amylase activity was not affected significantly by surfactin supplementation $(P>0.05)$. The blood urea nitrogen levels, and acid phosphatase and alkaline phosphatase activity in 100, 150, and $200 \mathrm{mg} / \mathrm{kg}$ surfactin supplementation groups were significantly ameliorated $(P<0.05)$. The albumin level of $100 \mathrm{mg} / \mathrm{kg}$ surfactin supplementation group was significantly higher than that of the control group. Lysozyme activity of 50,100 , and $150 \mathrm{mg} / \mathrm{kg}$ surfactin supplementation groups was significantly higher than the control group $(P<0.05)$. In conclusion, we demonstrated a promotion of growth performance and improvement of intestinal digestive enzyme activity, and some serum biochemical parameters of the orange-spotted grouper juveniles by appropriate surfactin levels supplemented in diet.
\end{abstract}

* Corresponding author. Corresponding author: Tel: +86-592-6181420, Fax: +86-592-

6181476. e-mail: shaoweizhai@hotmail.com 


\section{I ntroduction}

Antimicrobial peptides (AMPs) are believed to be capable of replacing the use of antibiotics in aquaculture, due to their natural antimicrobial properties, broad spectrum activities, speed of action, and low propensity for development of bacterial resistance (Wang et al., 2015). Dietary supplementation with some AMPs has been reported to have positive effects on growth performance and immune function of fish (Peng et al., 2007; Zhou et al., 2008; He et al., 2014), while those AMPs are mainly produced by chemical synthesis and genetically engineered microorganisms (Wang et al., 2015). AMPs produced naturally from microorganisms have become a most interesting area in this field. Surfactin, an antimicrobial lipopeptide from secondary metabolites produced by several strains of Bacillus subtilis, is a cyclic lipoheptapeptide containing seven amino acids and a $\beta$-hydroxyl fatty acid $\left(\mathrm{C}_{13}-\mathrm{C}_{15}\right)$. Much attention has been given to this over the past two decades because it exhibits numerous pharmaceutical activities as AMPs. Surfactin is distinguished by its interesting biological activities. For example, it shows potent antimicrobial, antiviral, antitumor, and hemolytic activities, which are of high relevance in health care and biotechnology application (Seydlova and Svobodova, 2008; Liu et al., 2010; Chen et al., 2015). In previous studies, dietary surfactin supplementation improved growth performance of tilapia (Oreochromis niloticus) (Shi et al., 2014a), marbled eel (Anguilla marmorata) (Zhai et al., 2016a), and Pacific white shrimp (Litopenaeus vannamei) (Shi et al., 2014b). Up to now, little information regarding surfactin supplementation in grouper was available. Grouper is a popular food fish cultured in Southeast Asia and a potentially important aquaculture species because of its rapid growth, efficient feed conversion, and high market value. The orange-spotted grouper (Epinephelus coioides) belongs to the family of Serranidae and is a coral fish with high commercial value and is easier to culture than certain other grouper species (Pierre et al., 2008; Wang et al., 2014). The cultivation of this expensive fish has been the focus of mariculture in Southeast Asia, especially in China ( $\mathrm{Li}$ et al., 2013). This study was conducted to investigate whether dietary surfactin supplementation produces any beneficial effects on growth performance, intestinal digestive enzymes activities, and various serum biochemical parameters of orange-spotted grouper juveniles.

\section{Materials and Methods}

Fish and Experimental design. One thousand healthy orange-spotted grouper juveniles were purchased in XiaoDeng Aquatic Science and Technology Co Ltd of Xiamen (Fujian Province, China). After adaptation to experimental conditions for two weeks, 360 orange-spotted grouper juveniles with the initial average body weight of $46.67 \pm 0.07 \mathrm{~g}$ were selected and randomly divided into six treatment groups with four replicates in each group and 15 fish in each replicate. Fish were fed the diets with surfactin levels of, 0 (control group), 25, 50, 100,150, and $200 \mathrm{mg} / \mathrm{kg}$, respectively. The trial continued for 56 days.

Diets and fish rearing conditions. The basal diet was formulated according to the national standard of China (GB/T22919.6-2008). Ingredients and proximate analyses of basal diet are presented in Table 1 . Six experimental diets were formulated to contain various concentrations of surfactin. The different levels of surfactin (content $>80 \%$, provided by Fujian Zhengyuan Feed Co., Ltd., Putian, China) were supplemented in the basal diet. All feed ingredients were thoroughly mixed and cold pelleted with a laboratory pelleting machine using a $2.5-\mathrm{mm}$ diameter module. After processing, the diets were packed into plastic zipper bags and stored at $-20^{\circ} \mathrm{C}$ until use. 
Table 1. Composition and nutrient levels of the basal diet (air-dry basis)

\begin{tabular}{llll}
\hline Ingredients & Content, $\%$ & Nutrient levels & Content, \% \\
\hline Fish meal & 42.0 & Dry matter & 92.76 \\
Shrimp meal & 3.0 & Crude protein & 47.73 \\
Soybean meal & 27.0 & lipid & 10.28 \\
Wheat flour & 19.9 & Ash & 10.15 \\
Fish oil & 2.0 & & \\
Soybean oil & 2.0 & & \\
Lecithin & 2.0 & & \\
Vitamin Premix & 0.3 & & \\
Mineral Premix & 0.5 & & \\
Choline chloride & 0.3 & & \\
Ca( $\left.\mathrm{H}_{2} \mathrm{PO}_{4}\right)_{2}$ & 1.0 & & \\
Total & 100.0 & & \\
\hline
\end{tabular}

Notes: Vitamin premix provided the following per $\mathrm{kg}$ of the diet: thiamine $0.25 \mathrm{mg}$, riboflavin $0.25 \mathrm{mg}$, nicotinic acid $1.0 \mathrm{mg}$, calcium pantothenate $1.25 \mathrm{mg}$, folic acid 0.075 $\mathrm{mg}$, biotin $0.03 \mathrm{mg}$, pyridoxine hydrochloride $0.2 \mathrm{mg}$, cobalamin $0.0005 \mathrm{mg}$, vitamin C 5 $\mathrm{mg}$, vitamin $\mathrm{K} 0.2 \mathrm{mg}$, inositol $10 \mathrm{mg}$, vitamin E $2 \mathrm{mg}$, vitamin A $0.2 \mathrm{mg}$. Mineral premix provided the following per $\mathrm{kg}$ of the diet: $\mathrm{MgSO}_{4} \cdot 7 \mathrm{H}_{2} \mathrm{O} 15 \mathrm{mg}, \mathrm{NaCl} 1.0 \mathrm{mg}, \mathrm{NaH}_{2} \mathrm{PO}_{4} \cdot 2 \mathrm{H}_{2} \mathrm{O}$ $25 \mathrm{mg}, \mathrm{KH}_{2} \mathrm{PO}_{4} 32 \mathrm{mg}, \mathrm{FeSO}_{4} 2.5 \mathrm{mg},\left(\mathrm{CH}_{3} \mathrm{CHOHCOO}_{2}\right) \mathrm{Ca} \cdot 5 \mathrm{H}_{2} \mathrm{O} 3.5 \mathrm{mg}, \mathrm{ZnSO}_{4} \cdot 7 \mathrm{H} 2 \mathrm{O} 0.353$ $\mathrm{mg}, \mathrm{MnSO}_{4} \cdot 4 \mathrm{H}_{2} \mathrm{O} 0.162 \mathrm{mg}, \mathrm{CuSO}^{4} \cdot 5 \mathrm{H}_{2} \mathrm{O} 0.031 \mathrm{mg}, \mathrm{CoCl}_{2} \cdot 6 \mathrm{H}_{2} \mathrm{O} 0.01 \mathrm{mg}, \mathrm{KIO}_{3} 0.003 \mathrm{mg}$.

Prior to the onset of the trial, the orange-spotted grouper were acclimatized in two plastic tanks (60 cm diameter, $100 \mathrm{~cm}$ height, $800 \mathrm{~L}$ water volume), and were fed the basal diet twice daily for 2 weeks during the adaptation period, after which the fish were kept in 24 rectangular aquaria $(75 \mathrm{~cm} \times 55 \mathrm{~cm} \times 60 \mathrm{~cm})$. The water volume of each aquarium was about 130 litres. The filtered seawater was supplied to the culture system with additional aeration provided by an air pump. The amount of the daily changing water was 30-50\%. Fish were fed to satiation three times daily (at 8:00 h, 13:00 $\mathrm{h}$ and 18:00 h). Uneaten pellets and feces were siphoned out before each meal. The water quality was monitored twice weekly with a multiparameter photome (HI9804N, HANNA, Baranzate, $\mathrm{MI}$, Italy). The values of dissolved oxygen, $\mathrm{pH}$ and ammonia- $\mathrm{N}$ ranged between 6 to $8 \mathrm{mg} / \mathrm{L}$, 8.0 to 8.2 and 0 to $0.2 \mathrm{mg} / \mathrm{L}$, respectively. The water temperature ranged from 26 to $28{ }^{\circ} \mathrm{C}$.

Sample collection and analysis. At the end of the trial, six fish were sampled at random from each replicate and anesthetized by dipping in $75 \mu \mathrm{l} / \mathrm{L}$ of eugenol oil suspension in water for 30s. Then the blood samples were collected from the caudal vein of each fish. After holding them at $4^{\circ} \mathrm{C}$ for $30 \mathrm{~min}$, the blood samples was centrifuged at $3500 \mathrm{rpm}$ for $10 \mathrm{~min}$ at $4^{\circ} \mathrm{C}$, and the supernatant serum was collected and stored prior to biochemical analysis at $-80^{\circ} \mathrm{C}$. The blood samples were collected from each sample and the fish were weighed, sacrificed, and kept in an ice bath for intestine sampling. The intestines from each replicate were pooled and homogenized in 10 volumes ( $\mathrm{v} / \mathrm{w})$ of icecold normal saline $(0.68 \%)$. The homogenates were centrifuged at $10,000 \mathrm{rpm}$ for 15 min at $4^{\circ} \mathrm{C}$ and the supernatants with the enzyme extracts collected and stored at $-80^{\circ} \mathrm{C}$ until assayed.

The activities of amylase, lipase and protease in the intestine and proximate composition of experimental diets were measured according to the method of Zhai and Liu (2014). The levels of blood urea nitrogen (BUN) and Albumin (ALB) in serum activities of acid phosphatase (ACP), alkaline phosphatase (AKP), and lysozyme (LZM) were determined using commercial clinical investigation kits (Nanjing Jiancheng Bioengineering Institute, Nanjing, China). All serum parameters were analyzed by an automatic biochemical analyzer (Hitachi 7020, Tokyo, Japan).

Data Calculation. At the beginning and at the end of the trial, body weight of the fish was measured in each tank after one day of feed deprivation, and the food consumption was recorded. The initial body weight (IBW) and final body weight (FBW) of fish, weight gain rate (WGR), feed conversion ratio (FCR), feeding rate (FR) and survival rate (SR) were calculated as follows:

IBW $(\mathrm{g} / \mathrm{fish})=$ initial body weight of fish $(\mathrm{g}) /$ initial number of fish;

FBW $(\mathrm{g} / \mathrm{fish})=$ final body weight of fish $(\mathrm{g}) /$ final number of fish; 
WGR $(\%)=100 \times[$ final wet weight $(g)$ - initial wet weight $(g)] /$ initial wet weight $(\mathrm{g})$; $\mathrm{FCR}=$ feed intake $(\mathrm{g}) /$ weight gain $(\mathrm{g})$;

$\mathrm{FR}(\% / \mathrm{d})=100 \times$ feed intake $(\mathrm{g}) /[($ initial body weight $(\mathrm{g})+$ final body weight (g) )/2]/trial period (d);

SR $(\%)=100 \times$ (final number of fish/initial number of fish).

Statistical analysis. The results are presented as means \pm SD of four replicates. Statistical analysis was performed with SPSS 11.5 statistical software (SPSS, Chicago, IL, USA). Data from each treatment group were subjected to one-way analysis of variance (ANOVA). When overall differences were significant $(P<0.05)$, Duncan's multiple range test was used to compare the mean values among the treatment groups. Data expressed as percentages or ratios were subjected to arcsine transformation prior to statistical analysis.

\section{Results}

Growth performance. Growth performance values of the orange-spotted grouper juveniles are shown in table 2. The FBW and WGR in the $100 \mathrm{mg} / \mathrm{kg}$ surfactin supplementation group were significantly higher than those of the control group $(P<0.05)$. The $F C R$ in the $50 \mathrm{mg} / \mathrm{kg}$ and $100 \mathrm{mg} / \mathrm{kg}$ surfactin supplementation groups were significantly lower than those of the control group and $200 \mathrm{mg} / \mathrm{kg}$ surfactin supplementation group $(P<0.05)$. There were no significant differences of $F R$ and $S R$ between control group and all surfactin supplementation groups $(P>0.05)$. No significant differences in FBW, WGR, FR, and SR were found among surfactin supplemented groups $(P>0.05)$.

Table 2. Growth performance of orange-spotted grouper juveniles fed diets with different levels of surfactin supplementation

\begin{tabular}{|c|c|c|c|c|c|c|}
\hline \multirow{2}{*}{ Items } & \multicolumn{6}{|c|}{ Dietary surfactin level $(\mathrm{mg} / \mathrm{kg})$} \\
\hline & 0 & 25 & 50 & 100 & 150 & 200 \\
\hline IBW (g/fish) & $46.70 \pm 0.10^{a}$ & $46.63 \pm 0.05^{a}$ & $46.67 \pm 0.09^{a}$ & $46.69 \pm 0.04^{a}$ & $46.65 \pm 0.08^{a}$ & $46.68 \pm 0.05^{a}$ \\
\hline FBW (g/fish) & $144.76 \pm 4.26^{\mathrm{a}}$ & $152.95 \pm 6.01^{\mathrm{ab}}$ & $156.15 \pm 4.62^{\mathrm{ab}}$ & $164.89 \pm 9.65^{b}$ & $152.31 \pm 4.65^{\mathrm{ab}}$ & $146.41 \pm 6.98^{\mathrm{a}}$ \\
\hline WGR (\%) & $209.71 \pm 9.58^{\mathrm{a}}$ & $228.15 \pm 12.79^{\mathrm{ab}}$ & $234.38 \pm 10.36^{\mathrm{ab}}$ & $253.27 \pm 20.87^{b}$ & $226.76 \pm 10.38^{\mathrm{ab}}$ & $213.71 \pm 14.76^{a}$ \\
\hline FCR & $1.10 \pm 0.02^{\mathrm{b}}$ & $1.07 \pm 0.01^{\mathrm{ab}}$ & $1.02 \pm 0.04^{\mathrm{a}}$ & $1.02 \pm 0.01^{\mathrm{a}}$ & $1.06 \pm 0.01^{\mathrm{ab}}$ & $1.09 \pm 0.01^{\mathrm{b}}$ \\
\hline $\mathrm{FR}(\% / \mathrm{d})$ & $2.00 \pm 0.01^{\mathrm{a}}$ & $2.03 \pm 0.05^{a}$ & $1.99 \pm 0.05^{\mathrm{a}}$ & $2.00 \pm 0.06^{a}$ & $2.01 \pm 0.06^{a}$ & $2.01 \pm 0.05^{\mathrm{a}}$ \\
\hline $\mathrm{SR}(\%)$ & $100^{\mathrm{a}}$ & $100^{\mathrm{a}}$ & $100^{\mathrm{a}}$ & $100^{a}$ & $100^{\mathrm{a}}$ & $100^{a}$ \\
\hline
\end{tabular}

$\mathrm{IBW}=$ initial body weight; $\mathrm{FBW}=$ final body weight; $\mathrm{WGR}=$ weight gain rate; $F C R=$ feed conversion ratio; $\mathrm{FR}=$ feeding rate; $\mathrm{SR}=$ survival rate.

${ }^{a b c}$ Values within the same row with different superscript were significantly different at $\mathrm{P}<0.05$ level.

Activities of digestive enzymes in intestine. Digestive enzyme activities in the intestines of the sampled fish are shown in Table 3. Compared with control group, the activities of protease and lipase in intestine of 50,100 , and $150 \mathrm{mg} / \mathrm{kg}$ surfactin supplementation groups were significantly higher than those of the control group $(P<0.05)$. Amylase activity was not affected significantly by surfactin supplementation $(P>0.05)$. The values of digestive enzyme activities in $100 \mathrm{mg} \mathrm{mg} / \mathrm{kg}$ surfactin supplementation group were highest among all the groups.

Table 3. Digestive enzyme activities of orange-spotted grouper juveniles fed diets with different levels of surfactin supplementation

\begin{tabular}{|c|c|c|c|c|c|c|}
\hline \multirow{2}{*}{ Items } & \multicolumn{6}{|c|}{ Dietarv surfactin level (ma/ka) } \\
\hline & 0 & 25 & 50 & 100 & 150 & 200 \\
\hline $\begin{array}{l}\text { Protease } \\
\text { (U/mg prot) }\end{array}$ & $12.34 \pm 2.29^{a}$ & $15.97 \pm 2.73^{\mathrm{ab}}$ & $17.57 \pm 1.03^{b}$ & $17.28 \pm 1.40^{\mathrm{b}}$ & $17.04 \pm 2.83^{b}$ & $14.01 \pm 2.52^{\mathrm{ab}}$ \\
\hline $\begin{array}{l}\text { Lipase } \\
\text { (U/g prot) }\end{array}$ & $29.00 \pm 0.64^{a}$ & $30.28 \pm 0.53^{\mathrm{ab}}$ & $31.13 \pm 1.33^{\mathrm{bc}}$ & $32.09 \pm 1.31^{c}$ & $31.23 \pm 0.49^{\mathrm{bc}}$ & $30.26 \pm 1.04^{\mathrm{ab}}$ \\
\hline $\begin{array}{l}\text { Amylase } \\
\text { (U/mg prot) }\end{array}$ & $0.12 \pm 0.02^{a}$ & $0.12 \pm 0.01^{a}$ & $0.12 \pm 0.01^{\mathrm{a}}$ & $0.13 \pm 0.01^{\mathrm{a}}$ & $0.13 \pm 0.02^{\mathrm{a}}$ & $0.11 \pm 0.01^{a}$ \\
\hline
\end{tabular}


Serum Biochemical Parameters. The results of serum biochemical parameters are presented in table 4 . The BUN levels of 100, 150, and $200 \mathrm{mg} / \mathrm{kg}$ surfactin supplementation groups were significantly lower than those of the control group $(P<0.05)$. Only $100 \mathrm{mg} / \mathrm{kg}$ surfactin supplementation group's ALB level was higher that of control group $(P<0.05)$. The activities of ACP and AKP in 100,150 , and $200 \mathrm{mg} / \mathrm{kg}$ surfactin supplementation groups were significantly higher than those of control group $(P<0.05)$. The LZM activities of 50,100 , and $150 \mathrm{mg} / \mathrm{kg}$ surfactin supplementation groups were significantly higher than those of control group $(\mathrm{P}<0.05)$.

Table 4. Serum Biochemical Parameters of orange-spotted grouper juveniles fed diets with different levels of surfactin supplementation

\begin{tabular}{lllllll}
\hline \multirow{2}{*}{ Items } & \multicolumn{6}{l}{ Dietary surfactin level $(\mathrm{mg} / \mathrm{kg})$} \\
\cline { 2 - 6 } & 0 & 25 & 50 & 100 & 150 & 200 \\
\hline BUN $(\mathrm{mmol} / \mathrm{L})$ & $1.55 \pm 0.05^{\mathrm{c}}$ & $1.44 \pm 0.09^{\mathrm{bc}}$ & $1.50 \pm 0.09^{\mathrm{c}}$ & $1.29 \pm 0.01^{\mathrm{a}}$ & $1.28 \pm 0.07^{\mathrm{a}}$ & $1.35 \pm 0.05^{\mathrm{ab}}$ \\
$\mathrm{ALB}(\mathrm{g} / \mathrm{L})$ & $10.11 \pm 0.45^{\mathrm{a}}$ & $10.40 \pm 0.51^{\mathrm{a}}$ & $10.40 \pm 0.66^{\mathrm{a}}$ & $11.75 \pm 0.91^{\mathrm{b}}$ & $11.12 \pm 0.62^{\mathrm{ab}}$ & $10.85 \pm 0.39^{\mathrm{ab}}$ \\
$\mathrm{ACP}(\mathrm{U} / \mathrm{dL})$ & $2.60 \pm 0.22^{\mathrm{a}}$ & $2.98 \pm 0.38^{\mathrm{abc}}$ & $2.91 \pm 0.18^{\mathrm{ab}}$ & $3.34 \pm 0.16^{\mathrm{c}}$ & $3.16 \pm 0.18^{\mathrm{bc}}$ & $3.09 \pm 0.14^{\mathrm{bc}}$ \\
$\mathrm{AKP}(\mathrm{U} / \mathrm{dL})$ & $9.78 \pm 0.23^{\mathrm{a}}$ & $10.40 \pm 0.54^{\mathrm{a}}$ & $10.91 \pm 0.84^{\mathrm{ab}}$ & $12.81 \pm 0.99^{\mathrm{c}}$ & $11.86 \pm 0.53^{\mathrm{bc}}$ & $10.84 \pm 0.25^{\mathrm{ab}}$ \\
$\mathrm{LZM}(\mathrm{U} / \mathrm{mL})$ & $101.15 \pm 10.71^{\mathrm{a}}$ & $125.25 \pm 18.36^{\mathrm{b}}$ & $133.33 \pm 11.25^{\mathrm{b}}$ & $128.09 \pm 7.45^{\mathrm{b}}$ & $120.95 \pm 16.37^{\mathrm{ab}}$ & $118.69 \pm 7.41^{\mathrm{ab}}$ \\
\hline
\end{tabular}

$\mathrm{BUN}=$ blood urea nitrogen; $\mathrm{ALB}=$ albumin; $\mathrm{ACP}=$ acid phosphatase; $\mathrm{AKP}=$ alkaline phosphatase; $\mathrm{LZM}=\mathrm{lys} 0 \mathrm{z} y \mathrm{me}$ (LZM).

abc

Values within the same row with different superscripts were significantly different at $\mathrm{P}<0.05$ level.

\section{Discussion}

In the present study, growth performance of orange-spotted grouper was significantly improved by dietary $100 \mathrm{mg} / \mathrm{kg}$ surfactin supplementation. These growth promotion effects of dietary surfactin supplementation were also found in other aquatic animals. It was reported that growth performance of tilapia fed a diet with $50 \mathrm{mg} / \mathrm{kg}$ surfactin supplementation was highest among all treatment groups (Shi et al., 2014a). While the best growth performance of $25 \mathrm{mg} / \mathrm{kg}$ surfactin group in marbled eel was observed (Zhai et al., 2016a). Shi et al. (2014b) reported that $100 \mathrm{mg} / \mathrm{kg} \mathrm{NT}-6$ antimicrobial lipopeptide (the mixture of surfactin, iturins and fengycins) had significant improvement on growth performance of Pacific white shrimp. The optimal surfactin supplementation level to promote growth performance in the present study was somewhat different from those of other aquatic animals. This can be explained by the differential surface activity of surfactin on cell membranes (Seydlova and Svobodova, 2008; Chen et al., 2015). Future studies should help to reveal the detailed mechanisms of growth promotion effect of surfactin in grouper.

In the present study, apart from amylase activity which was not significantly affected, all other activities of the digestive enzymes in intestine, were significantly enhanced when the experimental fish feeds were supplemented with surfactin for $56 \mathrm{~d}$. Similar results were found in the tilapia study of Shi et al. (2014a), which showed that the activities of lipase and protease in the intestines increased significantly with $12.5,25$, and $50 \mathrm{mg} / \mathrm{kg}$ surfactin supplementation. In the study of retarded marbled eel, lipase and protease activity were also significantly enhanced by $25 \mathrm{mg} / \mathrm{kg}$ surfactin supplementation (Zhai et al., 2016a). The mechanisms of surfactin promoting the activities of digestive enzymes are probably involved in the improvement of intestinal health (Wang et al., 2015; Zhai et al., 2016b). It has been shown that AMPs affect maintenance of intestinal epithelial barrier integrity by stimulation of mucus synthesis, promoting the production of tight junction proteins and repair of the intestinal barrier. AMPs can also function as potent immune regulators and protect the intestinal surface (Wang et al., 2015). It has been reported that tilapia fed a diet supplemented with AMPs surfactin demonstrated increased intestinal folds height, regulated intestinal microbial population, and antioxidant ability of intestinal tract, which was related to the functions of surfactin in gut homeostasis (Zhai et al., 2016b). Further study is needed to reveal the detailed mechanisms of surfactin improvement of the intestinal health of orange-spotted grouper.

The change in serum BUN concentrations reflects the whole body status of amino acid metabolism and utilization in animals. Thus, decrease of serum BUN concentration of 
surfactin supplementation groups might suggest a potential enhancement of synthesis of protein in animals (Wu et al., 2013). Albumin is an easily available protein reserve and a protein transporter (Anderson et al. 1979). Increased albumin is considered a strong innate response in fish (Wiegertjes et al. 1996). ACP is a typical lysosomal enzyme that kills and digests microbial pathogens and AKP is a kind of multifunctional enzyme in the immune defense system of fish, capable of promoting phagocytosis through modification of the pathogen surface molecules (Yin et al., 2014). The serum lysozyme is used as an indicator of innate immune response in fish (Tort et al. 2003).It plays an important role in innate immunity by lysis of bacterial cell wall and thus stimulates the phagocytosis of bacteria (Ellis, 1990). The lower BUN levels of surfactin supplemented groups in this study indicate that the orange-spotted grouper might have higher efficiency of dietary protein. The higher levels of ALB, ACP, AKP and LZM in the $100 \mathrm{mg} / \mathrm{kg}$ surfactin supplemented groups in this study indicate that the orange-spotted grouper might have strong innate immune capability. But these have still to be proved experimentally. From the results of the present trial, we found that the growth performance and some intestinal digestive enzymes activities and serum biochemical parameters of orangespotted grouper were improved with supplementation up to a rate of $100 \mathrm{mg} / \mathrm{l}$ but not with higher rates. This suggests that there is a threshold concentration for its solubilization (Seydlova and Svobodova, 2008; Chen etal., 2015).

In summary, the present study showed that the appropriate surfactin level supplemented in diet of orange-spotted grouper juveniles had beneficial effect on the growth performance, some intestinal digestive enzymes activities and serum biochemical parameters.

\section{Acknowledgements}

The financial support provided by Special Project of International Science and Technology Cooperation and Exchange of Ministry of Science and Technology (Grant No.2014DFT30150), Science and Technology Major/Special Project of Fujian Province (No. 2016NZ0001-3), Nature Science Foundation of Fujian Province (Grant No. 2016J 01166), and Community Project of Mr. Yang Sheng's Student (No.2016A30010) are gratefully acknowledged.

\section{References}

Anderson D.P., Robertson B.S., Dixon O.W., 1979. Plaque-forming cells and humoral antibody in rainbow trout (Salmo gairdneri) induced by immersion in a Yersinia ruckeri Oantigen preparation. J. Fish Res. Board Can., 36(6):636-639.

Chen W.C., Juang R.S., Wei Y.H., 2015. Applications of a lipopeptide biosurfactant, surfactin, produced by microorganisms. Biochem. Eng. J., 103:158-169.

Ellis A.E., 1990. Immunity to bacteria in fish. Fish Shellfish Immunol., 9(4): 291-308.

He Y., Liu B., Xie J., Ge X., Xu P., Lu Y., Lu F., Lu Z., 2014. Effects of antibacterial peptide extracted from Bacillus subtilis fmbJ on the growth, physiological response and disease resistance of Megalobrama amblycephala. Isr. J. Aquacult.Bamidgeh, If A 66.2014.952, 11 pages.

Li Y., Liu X., Zhang Y., Ma X., Lin, H., 2013. Effects of cysteamine on mRNA levels of growth hormone and its receptors and growth in orange-spotted grouper (Epinephelus coioides). Fish Physiol. Biochem., 39(3):605-613.

Liu J., Zou A.H, Mu B.Z., 2010. Surfactin effect on the physicochemical property of PC liposome.Colloids and Surfaces A: Physicochem. Eng. Aspects, 361:90-95.

Ministry of Agriculture of the Peoples Republic of China, 2008. GB/T 22919.6-2008 Formulated feed of grouper. China Standard Press, Beijing, China, pp1-6.

Peng K.S., She R.P., Yang Y.R., Zhou X.M., Liu W., Wu J., Bao H.H., Liu T.L., 2007. Anti-adherence of antibacterial peptides and oligosaccharides and promotion of growth and disease resistance in tilapia. Asian Australas. J. Anim. Sci., 20(4):569-576.

Pierre S., Gaillard S., Prévot-D'Alvise N., Aubert J., Rostaing-Capaillon O., Leung-Tack D., Grillasca J.P., 2008. Grouper aquaculture: Asian success and Mediterranean trials. Aquat Conserv Mar Freshw Ecosyst., 18(3):297-308.

Seydlova, G., Svobodova J., 2008. Review of surfactin chemical properties and the potential biomedical applications. Cent. Eur. J. Med., 3(2): 123-133. 
Shi Q.C., Lu J.J., Lu P., Guo Q.X., Zhai S.W., 2014a. Effects of antimicrobial lipopeptides supplementation on growth performance and intestinal digestive enzyme activities of genetic improvement of farmed tilapia (GIFT, Oreochromis niloticus). J. Feed Ind. 35(12): 6-10.

Shi G., Sun L.J, Wang Y.L., Liu H.M., Xu D.F., Nie F.H., Liu Y., Ye R.Y., 2014b.

Effects of NT- 6 antimicrobial lipopeptide on growth performance of Litopenaeus vannamei and Vibrio number during breeding process. Guangdong J. Agr. Sci., 41(12):119$122,137$.

Tort L., Balasch J.C., Mackenzie S., 2003. Fish immune system. A cross roads between innate and adaptive responses. Imunología., 3:277-286.

Wang S., Thacker P.A., Watford M, Qiao S., 2015. Functions of antimicrobial peptides in gut homeostasis. Curr. Protein Pept. Sci., 16: 582-591.

Wang Y.D., Huang S.J., Chou H.N., Liao W.L., Gong H.Y., Chen J.Y., 2014. Transcriptome analysis of the effect of Vibrio alginolyticus infection on the innate immunity-related complement pathway in Epinephelus coioides. BMC Genomics, 15(1): 1102.

Wiegertjes G.F., Stet R.J.M., Parmeatier H.K., Van Muiswinkel W.B., 1996. Immunogenetics of disease resistance in fish: a comparable approach developmental and comparative Immunology. J. Exp. Biol., 20:365-381.

Wu Z.X., Pang S.F.,Chen X.X.,Yu Y.M.,Zhou J.M., Chen X., Pang L.J ., 2013. Effect of Coriolus versicolorpolysaccharides on the hematological and biochemical parameters and protection against Aeromonas hydrophila in allogynogenetic crucian carp (Carassius auratus gibelio). Fish Physiol. Biochem., 39(2):181-190.

Yin F., Dan X. M., Sun P., Shi Z. H., Gao Q. X., Peng S. M., Li A. X., 2014. Growth, feed intake and immune responses of orange-spotted grouper (Epinephelus coioides) exposed to low infectious doses of ectoparasite (Cryptocaryon irritans).Fish Shellfish Immun.,36(1): 291-298.

Zhai S.W., Liu S.L., 2014. Effects of Dietary quercetin on the growth performance, digestive enzymes and antioxidant potential in the hepatopancreas of tilapia (Oreochromis niloticus). Isr. J. Aquacult.-Bamidgeh, IJ A_66.2014.1038, 8 pages.

Zhai S.W., Shi Q.C., Chen X.H., 2016a.Effects of dietary surfactin supplementation on growth, digestive enzymes activities and antioxidant potential in intestine of growth retarded marbled eel (Anguilla marmorata) at elver stage. Isr. I. Aquacult.Bamidgeh, IJ A_68.2016.1282, 7 pages.

Zhai S.W., Shi Q.C., Chen X.H., 2016b. Effect of dietary antimicrobial peptidessurfactin supplementation on parameters of intestinal health indices of genetically improved farmed tilapia (GIFT, Oreochromis niloticus). Acta Hydrobiologica Sinica, 40:823-829.

Zhou X.X., Wang Y.B., Li W.F., 2008. Effect of feeding apidaecin on common carp (Cyprinus carpio) growth performances and immune function. Aquaculture, 279: 108-112. 